

\title{
Convocation Speech At Indian Statistical Institute
}

\author{
BY DR. JOACHIM FRANK
}

Dept. of Biochemistry and Molecular Biophysics

\& Dept. of Biological Sciences, Columbia University, New York, USA

\begin{abstract}
Frank took his convocation speech in January 2020 at the Indian Statistical Institute in Calcutta as an occasion to recall his own graduation events in Freiburg and Munich, and the tumultuous time, in the 60s, of Germany's soulsearching anti-authoritarian movement, just 20 years after the end of the perilous Nazi regime.
\end{abstract}

Keywords: anti-authorianism, cryo-electron microscopy, democracy, reiburg, Global Warming, Hitler, Munich, Shah of Persia.

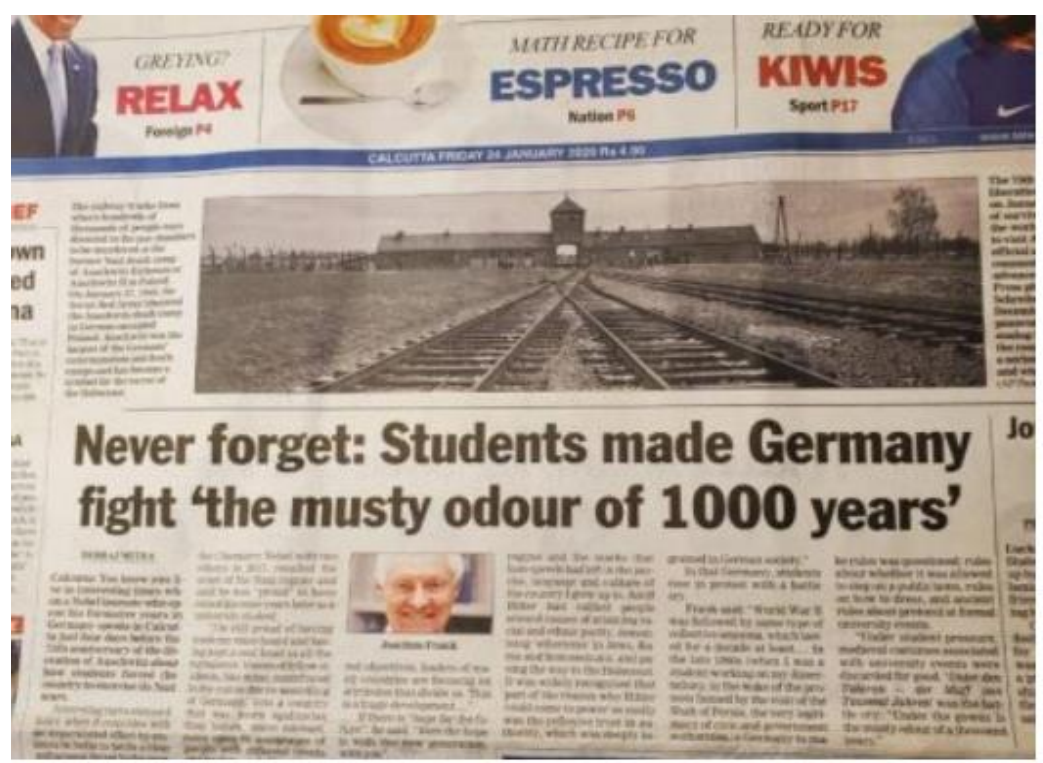

Above: front page of the Telegraph, an Indian daily newspaper, on January 24.

Posted below is the verbatim text of the speech I gave at the convocation of the Indian Statistical Institure on January 23, 2020. It differs from the text in the pamphlet distributed at the event at a few places. One is the incorrect date that I gave for my graduation in Freiburg: 1963, not 1967. 
Respected President, respected Director, dear members of the Faculty, dear Students and Guests:

As a student and later as a faculty member I have attended numerous convocations, and listened to numerous convocation sb peeches. Inevitably more than once the question arose in my wandering mind what I would say at such august occasion to a large audience of new graduates if I were ever invited to stand on this podium. Miraculously, through the powers of the Nobel Foundation, I have now been handed the megaphone to talk about anything - be it related or unrelated to the narrow field of my study.

First of all, why would a physicist working in Biology, after winning a Nobel Prize in Chemistry, be invited to talk to the Indian Statistical Institute? Well, I can only guess, but the story starts more than 40 years ago. As I was trying to develop methods to reconstruct biological molecules from thousands of individual projections deeply buried in noise, I was forced to deal with a lot of areas related to Statistics: correlation functions, multivariate statistical analysis, pattern recognition, three-dimensional Fourier transforms, statistical optics, and what would now be called Deep Data Analysis. So with some justification I can consider myself part of the community of scholars in Applied Statistics, in an application that, through a quirk of fate, has become a major tool of Structural Biology, by now paralleling X-ray crystallography in power.

My day-to-day activity in those days - I'm talking about the nineteen-seventies and eighties - was programming, being completely oblivious to where I was and what time it was. I was using computers that had just a small fraction of the capacity of today's cell phone but still enough memory to get lost. When I think back to this time of total immersion in the code I was developing, I think of the exhilarating experience of living in a world I created all on my own. The functionality and formal beauty of that world, along with its faults, were entirely of my own doing. Essentially I was an architect living in the building I created and, when something was amiss, I was at liberty to change it on the spot. A crack in the ceiling? No problem - a new ceiling was put in place within minutes. A room too small? No problem - the walls could be moved with the flick of my fingers.

When I think back to that time I realize that part of the experience was the secret hope, if not expectation, that the real world might be able to be controlled in a similar manner. If the minds of responsible smart people could be harnessed together, then the 
combined competence from each ever-so-small area of science and technology could contribute to the solution of the world's problems.

This is where the naivety of a young student clashes with the reality he or she is surrounded with. The world we live in is far more complex, and insufficiently modeled, to lend itself to deterministic analysis. This world as I came to recognize is chaotic, nonlinear, full of hidden variables. But what is still true is that the rational, critical approach to problem solving, the "Scientific Approach" that we learn at universities and other institutions of higher education, is unsurpassed in guiding us in that world. And this brings me to the other part of my speech.

Right off the bat I have to dispel the idea that I have a recipe for how to launch your career, how to be successful, or how to deal with today's world. Everyone's situation is different, shaped by your unique personal experience, place, and constellation of history. I think the best advice is that you should follow your own compass which parents and teachers have implanted in you as you grew up. So instead of giving you a recipe, I will tell you about my own experience at a different place and time.

My own graduation was back in 1963 from the University of Freiburg in Germany, where I did my Vordiplom, or Bachelor of Science. But it's more to the point that I should speak of the other graduation seven years later, in 1970 from the Technical University of Munich, where I did my Ph.D. defense. So we are talking almost precisely half a century ago.

I had little confidence in myself and my abilities, and the world seemed a scary place. Worse than that, the whole world seemed in upheaval - the Vietnam War was still going on, bringing protests to many countries. In Germany, during the whole time I spent in Munich, another cause brought widespread discontent: thousands were on the street protesting the Shah of Persia's visit to Germany and the excessive German police force protecting him.

Germany, just 25 years after World War II ended, was still recovering from the inhuman onslaught of the Nazi regime and the marks that hate speech had left in the psyche, language and culture of the country I grew up in. Adolf Hitler had rallied people around causes of attaining racial and ethnic purity, demonizing "otherness" in Jews, Roma, and Homosexuals, and paving the way to the Holocaust. It was widely recognized that 
part of the reason why Hitler could come to power so easily was the reflexive trust in authority, which was deeply ingrained in German society.

Word War II was followed by some type of collective amnesia, which lasted for a decade at least. Then, in the late 1960s (when I was a student working on my dissertation), in the wake of the protests fanned by the visit of the Shah of Persia, the very legitimacy of civic and government authorities in Germany to make rules was questioned: rules about whether it was allowed to step on a public lawn, rules on how to dress, and ancient rules about protocol at formal university events. Under student pressure, medieval costumes associated with university events were discarded for good. "Unter den Talaren - der Muff von Tausend Jahren" - was the battle cry: "Under the gowns / Is the musty odour of a thousand years."

Looking back to those years, I'm still proud of having made my voice heard and having kept a cool head in all the turbulence. Voices of fellow students, like mine, contributed in the end to the re-molding of Germany, into a country that was more egalitarian than before, more tolerant, more open to acceptance of people with different creeds and backgrounds.

If anything, today's world is even more complex and poses more challenges than the world I experienced as a student. The steady progress in international cooperation after the end of the Cold War has given way to a dismal chaotic strife, almost reminding us of the state of affairs in the Middle Ages, before Enlightenment. Instead of looking for commonality and shared objectives, leaders of many countries are focusing on attributes that divide us. This is a tragic development since it happens just at the time when we need unity more than ever, as we all search for solutions in the galloping Global Warming crisis. Not too far away from here, an entire continent was in flames just recently. The effects of pollution you can see in your own country first-hand.

Fortunately, each generation brings in new energy, new ideas. Long-standing problems are re-framed by new inquisitive minds, often with surprising results. For many young students used to surf the internet and communicate over long distances, the boundaries of countries, bureaucratic regulations governing travel and citizenship seem completely antiquated, a thing of the past. Clearly, the world order needs to be re-thought in its entirety. To quote Joyce Carol Oates, "In matters of morality and behavior, it is rare that an 'older generation' will change. Rather, life simply moves on, 
the 'older generation' dies off, and a new generation with new concerns takes its place in something like a bloodless coup."

If there is hope for the future, in other words, then the hope is with the new generation, with you!

With this I would like to be one of the first to congratulate you and your parents and extended family for graduating from the Indian Statistical Institute, for a job well done!

\section{About the author:}

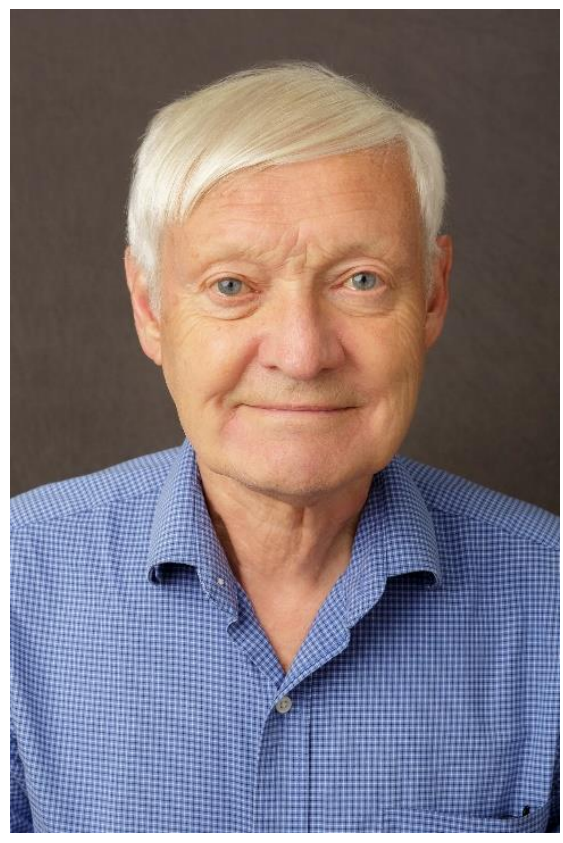

Frank has developed the mathematical foundations of structure determination by single-particle cryoelectron microscopy (cryo-EM). He received the Nobel Prize in Chemistry in 2017 which he shared with Jacques Dubochet and Richard Henderson. Using this unique technology, he made important contributions to the structure and function ribosomes from bacteria and eukaryotes. On March 6, 2019, Joachim Frank received an Honorary PhD Degree of the Universidad de Buenos Aires. In a very special event at the Faculty of Law at CUYO on March 8, 2019, he also received an Honorary PhD Degree of the Universidad Nacional de Cuyo in Mendoza, Argentina. At this event he was also honored by the Ambassadors of Germany and Switzerland.

Link to the original article: http://franxfiction.com/convocation-speech-at-indianstatistical-institute-jan-23-2020/ 